\title{
Efficacy of Ultrasound Intrinsic Compression Strain Elastography in Prediction of Malignancy in Thyroid Nodules with Fine Needle Aspiration Cytology Correlation
}

\author{
Rapelli Ramakrishna ${ }^{\circledR 1}$, Madhavi Thatipamula ${ }^{\circ 2}$ \\ ${ }^{1}$ Department of Radiodiagnosis, Yashoda Hospitals, Somajiguda, Hyderabad, Telangana, India, ${ }^{2}$ Department of Radiodiagnosis, Niloufer Hospital, Hyderabad, \\ Telangana, India.
}

\section{Abstract}

Background: Different diagnostic modalities are used to evaluate and diagnose efficiently thyroid nodules. These include Clinical Examinations, Thyroid Function Test (TFT), Scintiscan, Ultrasonography (USG), Fine Needle Aspiration Cytology (FNAC), and Histopathological examination. However, clinical assessment, TFT and USG have been poor parameters for assessing thyroid nodules. The objective is to this study was aimed to evaluate the efficacy of Ultrasound Elastography for the prediction of malignancy in thyroid nodule. Subjects and Methods:After obtaining written informed consent, demographic data such as age, sex and clinical features like, swelling, mode of onset, difficulty in swallowing, difficulty in breathing, hoarseness of voice obtained through an interview and recorded on predesigned and pretested proforma (Annexure II). Further these patients were subjected Grayscale Ultrasound, Ultrasound Elastography and FNAC. Results: Malignant lesions were noted in 19 patients on FNAC. Among them, 16 (84.21\%) patients had malignant lesions while $3(15.79 \%)$ patients had benign lesions based on combined USE and ECI criteria. This difference was statistically significant $(\mathrm{p}<0.001)$. The sensitivity of combined USE and ECI criteria in the diagnosis of malignant lesions was $84.21 \%$ with Specificity of $81.69 \%$, PPV $55.17 \%$ and NPV $95.08 \%$. Conclusion: Based on the findings of this study it may be concluded that, USE as determined by the Ragos criteria, TI RADS score are highly associated with malignant thyroid lesions and useful in differentiating the malignant thyroid lesions from benign ones.

Keywords: Thyroid Function Test (TFT), Scintiscan, Ultrasonography (USG), Fine Needle Aspiration Cytology (FNAC)

Corresponding Author: Madhavi Thatipamula, Department of Radiodiagnosis, Niloufer Hospital, Hyderabad, Telangana, India. E-mail: madhavithatipamula82@gmail.com

\section{Introduction}

Thyroid gland is unique among endocrine organs as it is the largest endocrine gland in the body and the first to develop in fetal life. Even after 100 years, thyroid gland has been the subject of intense research and considerable attention due to the vast array of developmental, inflammatory, hyperplastic and neoplastic disorders which are exceedingly common in clinical practice. ${ }^{[1]}$

Thyroid disease is of common occurrence, especially in iodine deficient areas. Thyroid nodule is an abnormal growth of thyroid cells into a lump within thyroid. These nodules have a reported prevalence of four to seven percent of adult population. ${ }^{[2]}$ The incidence of clinically apparent thyroid nodules in general population is four to five percent. ${ }^{[3]}$

Thyroid nodules represent a difficult diagnostic problem. Benign nodules can be caused by adenomas, colloid nodules, cysts, infectious nodules, lymphocytic or granulomatous nodules, hyperplastic nodules, thyroiditis, and congenital anomalies. Malignant nodules are classified as differentiated (Papillary adenocarcinoma, follicular adenocarcinoma), medullary carcinoma, undifferentiated (Small cell, giant cell and carcinosarcoma) and miscellaneous (Lymphoma, sarcoma, squamous cell carcinoma, fibrosarcoma, mucoepithelial carcinoma and metastatic tumors). However, the cancer rate is low. ${ }^{[4]}$ The incidence of malignancy in patients who undergo Fine Needle Aspiration Cytology (FNAC) is in the range of 9-14\%, independent of the number of nodules present. In multinodular thyroids the cancer risk per nodule is decreasing, approximately proportional to the increase of the number of nodules, therefore the cancer rate per patient remains the same as in single nodular thyroids. ${ }^{[4]}$

The usual presentation of thyroid disease is being swelling, pressure symptoms or signs of toxicity. ${ }^{[5]}$ Importance of dis- 
crete thyroid nodule lies in the risk of neoplasia as compared to other thyroid swellings. Different diagnostic modalities are used to evaluate and diagnose efficiently thyroid nodules. These include Clinical Examinations, Thyroid Function Test (TFT), Scintiscan, Ultrasonography (USG), Fine Needle Aspiration Cytology (FNAC), and Histopathological examination. However, clinical assessment, TFT and USG have been poor parameters for assessing thyroid nodules. ${ }^{[6]}$

On physical examination, a hard or firm nature is associated with thyroid malignancy. However, palpation is very subjective and limited in patients with multinodular goiter or small deep-seated nodules. ${ }^{[7]}$

Conventional USG has been widely used to determine which nodules should be biopsied. There are several suspicious USG features that predict thyroid cancer, such as hypoechogenicity, marked hypoechogenicity, a microlobulated or spiculated margin, micro- or macro-calcifications, and a taller-than-wide shape. ${ }^{[8]}$ Although conventional US can provide meaningful information in thyroid nodule diagnosis, there has been considerable variation in diagnostic performances. ${ }^{[9]}$

Ultrasonographic studies have suggested that USG alone is not sufficiently reliable to differentiate benign from malignant nodules. Final diagnosis requires morphological examination of lesions and for this FNAC or histological examination becomes mandatory. ${ }^{[10-15]}$ FNAC is widely accepted and has become cornerstone in evaluation of thyroid nodules because it is a simple and accurate screening test with high sensitivity and specificity in the preoperative evaluation of thyroid lesions. The routine use of FNAC in the assessment of thyroid nodules has reduced the number of patients subjected to thyroidectomy for benign diseases of the thyroid. ${ }^{[9]}$ Due to its simplicity, low cost and absence of major complications, this procedure is being performed on an increasing number of patients, which has led to the detection of thyroid cancers at earlier stages, resulting in better outcome of patients. Overall diagnostic efficacy of FNAC is $94.2 \%$.

Ultrasound elastography is a non-invasive tool, which was introduced by Ophir et al. ${ }^{[11]}$ in 1991, and it has shown a promising application for evaluating the stiffness of tissue. US-based elastography can provide an objective evaluation of tissue stiffness. ${ }^{[12]}$ There are two kinds of elastography (strain and shear wave elastography) that are currently used in radiological settings. ${ }^{[13]}$ Most malignant nodules are characterized by the composition of their abnormally firm stroma due to the presence of collagen and myofibroblasts, which make it possible to identify thyroid cancers using elastography imaging. Real-time elastography is only a qualitative ultrasound technique. ${ }^{[14]}$ Ultrasound elastography (USE) the most important addition to the armamentarium of sonographic techniques and it has been the main focus of thyroid USG imaging Research in the last decade. Hence, the final decision or radiological diagnosis is usually based on a combination of conventional US and elastography. However, the data on using various approaches for the evaluation of stiffness with USE is limited and yielded conflicting results. Although many reports have compared conventional US with elastography, these studies, however, are limited in sample size and have reported a wide range of sensitivities and specificities. ${ }^{[15]}$ This prompted us to evaluate the efficacy of USE for the prediction of malignancy in thyroid nodule with FNAC as a standard reference which may help to prevent unnecessary invasive diagnostic procedures in a substantial proportion of patients with completely soft benign nodules.

\section{Subjects and Methods}

Study design: The study design was a hospital based crossectional study.

Study period: The present study was conducted from June 2017 to May 2018.

Place: This study was carried out in the Department of Radiodiagnosis at Yashoda superspeciality hospital, Somajiguda, Hyderabad.

Source of Data : Patients referred to the radiology department with thyroid swelling and clinically suspected thyroid lesions.

Sample Size : A total of 100 patients with thyroid swelling and clinically suspected thyroid lesions were studied.

\section{Inclusion criteria:}

Patients with thyroid swelling and clinically suspected thyroid lesions referred for ultrasonography of thyroid.

\section{Exclusion criteria :}

- Previous surgery or radioiodine therapy

- Patients with predominantly cystic (anechoic nodules without solid components).

- Nodules in Isthmus.

- On ultrasound, thyroid nodules with peripheral calcification are excluded because posterior shadowing calcification produces artifacts (assessed on elastography examination).

- Patient with Hypertension and arrhythmias to avoid variability in intrinsic compression due to carotid pulsations.

After obtaining written informed consent, demographic data such as age, sex and clinical features like, swelling, mode of onset, difficulty in swallowing, difficulty in breathing, hoarseness of voice obtained through an interview and recorded on predesigned and pretested proforma (Annexure II). Further these patients were subjected Grayscale Ultrasound, Ultrasound Elastography and FNAC.

\section{Results}


Table 1: Distribution of the patients according to the Age group, Gender, Clinical features, Clinical Diagnosis and power doppler imaging findings

\begin{tabular}{|c|c|c|}
\hline \multirow[t]{2}{*}{ Gender } & \multicolumn{2}{|c|}{ Distribution $(\mathrm{n}=100)$} \\
\hline & Number & Percentage \\
\hline Male & 23 & 23.00 \\
\hline Female & 77 & 77.00 \\
\hline Total & 100 & 100.00 \\
\hline \multicolumn{3}{|l|}{ Age Group } \\
\hline 20 or less & 6 & 6.00 \\
\hline 21 to 30 & 15 & 15.00 \\
\hline 31 to 40 & 16 & 16.00 \\
\hline 41 to 50 & 26 & 26.00 \\
\hline 51 to 60 & 30 & 30.00 \\
\hline 61 to 70 & 5 & 5.00 \\
\hline 71 to 80 & 2 & 2.00 \\
\hline \multicolumn{3}{|l|}{ Clinical features } \\
\hline Swelling & 93 & 93.00 \\
\hline $\begin{array}{l}\text { Difficulty in swallow- } \\
\text { ing }\end{array}$ & 22 & 22.00 \\
\hline Difficulty in breathing & 11 & 11.00 \\
\hline Hoarseness of voice & 11 & 11.00 \\
\hline \multicolumn{3}{|l|}{ Clinical diagnosis } \\
\hline Benign & 78 & 78.00 \\
\hline Malignant & 22 & 22.00 \\
\hline \multicolumn{3}{|l|}{ Findings } \\
\hline Absent blood flow (I) & 11 & 11.00 \\
\hline $\begin{array}{l}\text { Peripheral blood } \\
\text { flow(II) }\end{array}$ & 51 & 51.00 \\
\hline $\begin{array}{l}\text { Central blood flow } \\
\text { (IIIA) }\end{array}$ & 22 & 22.00 \\
\hline $\begin{array}{l}\text { Central and peripheral } \\
\text { blood flow (IIIB) }\end{array}$ & 16 & 16.00 \\
\hline Absent blood flow (I) & 11 & 11.00 \\
\hline
\end{tabular}

\section{Discussion}

Thyroid nodules are relatively common and carry a low, but noticeable risk of malignancy. The most important challenge is differentiating benign from malignant nodules, and precise diagnosis and management of malignant nodules in the early stages. ${ }^{[16]} \mathrm{A}$ total of 100 patients who presented with thyroid swelling and were clinically suspected to have thyroid lesions were enrolled. These patients were subjected to imaging studies that is, grayscale ultrasound imaging, ultrasound elastography and these findings were correlated with FNAC diagnosis in order to evaluate the accuracy of ultrasound elastography and combined grayscale ultrasound imaging along with ultrasound elastography. The various radiological approaches for thyroid nodules range from conventional ultrasound till MRI updates (including Diffusion weighted imaging [DWI]) including radionuclide studies as isotope scanning and Fluorodeoxyglucose Positron Emission Tomography (FDG-PET). Conventional US considered the initial tool for detection and characterization of thyroid nodules. The present study was aimed to evaluate the efficacy of Ultrasound Elastography for the prediction of malignancy in thyroid nodule.

Epidemiological data suggests that, Thyroid nodules are less frequent in men than in women, ${ }^{[17]}$ accordingly in the present 


\begin{tabular}{|c|c|c|c|}
\hline \multirow[t]{2}{*}{ Grayscale Ultrasound } & \multirow[t]{2}{*}{ Findings } & \multicolumn{2}{|c|}{ Distribution $(\mathrm{n}=100)$} \\
\hline & & Number & Percentage \\
\hline \multirow[t]{4}{*}{ Composition (Score) } & Spongiform $(0)$ & 69 & 69.00 \\
\hline & $\begin{array}{l}\text { Solid or almost completely } \\
\text { solid (2) }\end{array}$ & 25 & 25.00 \\
\hline & Mixed cystic and solid (1) & 6 & 6.00 \\
\hline & Total & 100 & 100.00 \\
\hline \multirow[t]{5}{*}{ Echogenicity (Score) } & $\begin{array}{l}\text { Hyperechoic or isoechoic } \\
\text { (1) }\end{array}$ & 57 & 57.00 \\
\hline & Hypoechoic (2) & 31 & 31.00 \\
\hline & Very hypoechoic (3) & 12 & 12.00 \\
\hline & Anechoic (0) & 0 & 0.00 \\
\hline & Total & 100 & 100.00 \\
\hline \multirow[t]{3}{*}{ Shape (Score) } & Wider than tall (0) & 78 & 78.00 \\
\hline & Taller than wide (3) & 22 & 22.00 \\
\hline & Total & 100 & 100.00 \\
\hline \multirow[t]{4}{*}{ Margins (Score) } & Smooth $(0)$ & 75 & 75.00 \\
\hline & Lobulated or irregular (2) & 17 & 17.00 \\
\hline & $\begin{array}{l}\text { Extra thyroidal extension } \\
\text { (3) }\end{array}$ & 8 & 8.00 \\
\hline & Total & 100 & 100.00 \\
\hline \multirow[t]{5}{*}{ Echogenic foci (Score) } & $\begin{array}{l}\text { None or large comet tail } \\
\text { artifacts }(0)\end{array}$ & 100 & 100.00 \\
\hline & Macrocalcifications (1) & 0 & 0.00 \\
\hline & $\begin{array}{l}\text { Peripheral (rim) calcifica- } \\
\text { tions }(2)\end{array}$ & 0 & 0.00 \\
\hline & Punctate echogenic foci (3) & 0 & 0.00 \\
\hline & Total & 100 & 100.00 \\
\hline
\end{tabular}

study females outnumbered males as $77 \%$ of the patients were females and $33 \%$ of the patients were males with the male to female ratio of 1:3.34. Most of the patients were aged between 51 to 60 years (30\%) followed by 41 to 50 years $(26 \%)$. The means age was $44.37 \pm 14.02$ years. The mode of onset was gradual in all the patients and welling was the common clinical presentation noted in $93 \%$ of the patients. Based on clinical assessment, majority of the lesions were diagnosed as benign (78\%) lesions and $22 \%$ as malignant lesions.

Grayscale ultrasound imaging revealed spongiform composition in $69 \%$ of the patients. $57 \%$ of the patients had hyperechoic or isoechoic lesions. Majority of the patients (78\%) had wider than tall lesions. Smooth margins were noted in majority of the patients $(75 \%)$.

None of the patient had lesions suggestive of comet tail artifacts, macrocalcifications, peripheral (rim) calcifications, punctuate echogenic foci and calcifications.
$61 \%$ of the patients had ECI of $\leq 3.1$ and $39 \%$ of the patients had ECI of $>3.1$. The mean ECI was $2.30 \pm 1.67$.

Power Doppler imaging revealed most of the patients with peripheral blood flow (51\%) while, central blood flow was noted in $22 \%$ and central and peripheral blood flow in $16 \%$ and absent blood flow in $11 \%$ of the patients.

Based on TI RADS score, most of the patients has score suggestive of benign lesions $(50 \%)$ while high suspicious lesions were noted in $21 \%$ of the patients, moderately suspicious in $8 \%$, mildly suspicious in $2 \%$ and not suspicious in $19 \%$ of the patients. In this study based on Ragos criteria, $34 \%$ and $25 \%$ of the patients had score of 1 and 2 respectively suggestive of benign lesions. Score of 3 suggestive of intermediate lesions was noted in $10 \%$ of the patients and score of 4 and 5 suggestive of malignant lesions was noted in $23 \%$ and $8 \%$ of the patients respectively. In the present study, radiological diagnosis by combining USE with ECI revealed 
Table 3: Distribution of the patients according to the TI RADS score, elasticity contractility index, RAGOS criteria (score), radiological diagnosis based on combined USE and ECI

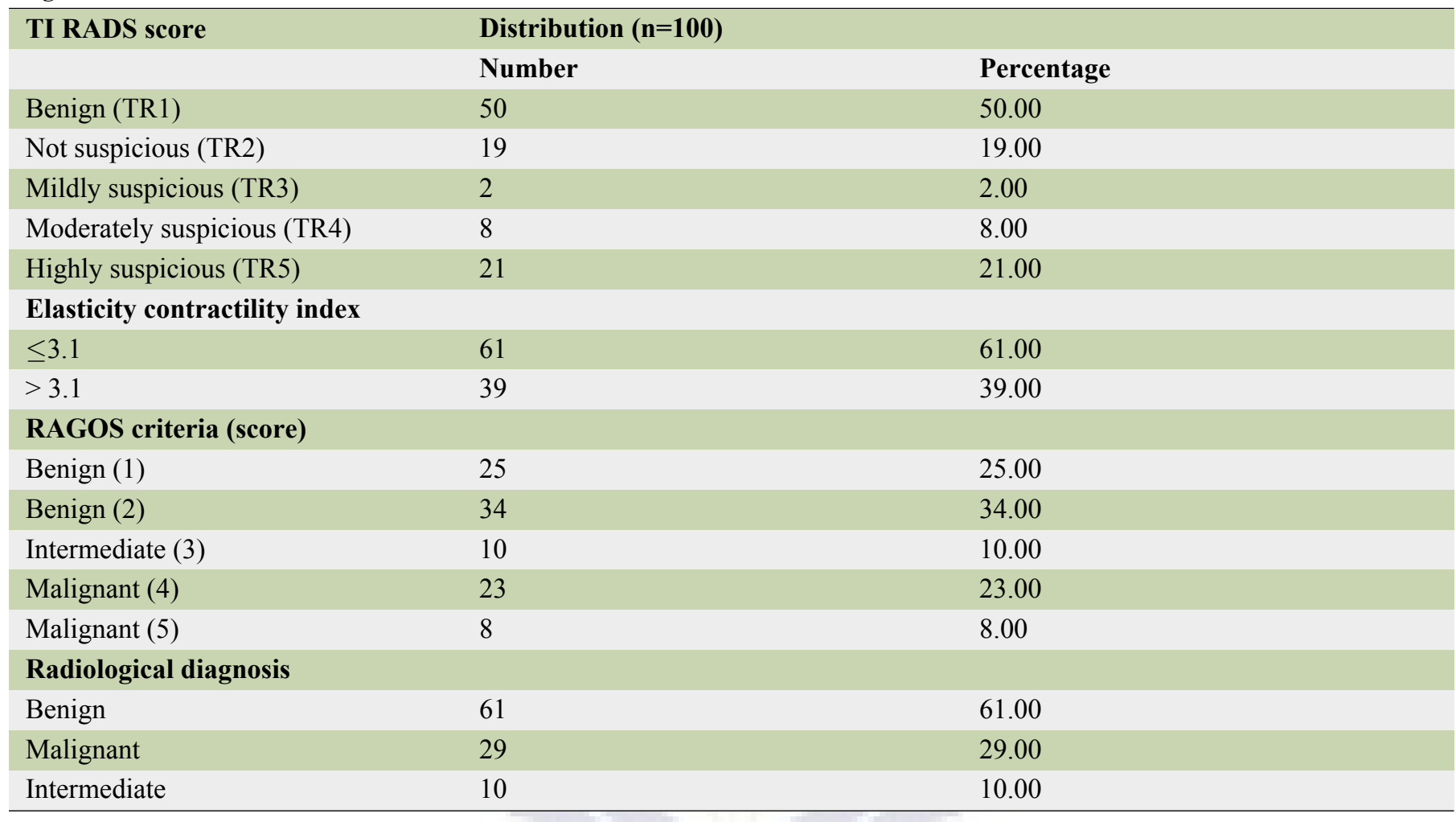

Table 4: Distribution of the patients according to the FNAC diagnosis, lesions based on FNAC Diagnosis

\begin{tabular}{lll}
\hline FNAC Diagnosis (BETHESDA System) & Distribution $(\mathbf{n}=\mathbf{1 0 0})$ & \\
& Number & Percentage \\
Colloid goitre & 32 & 32.00 \\
Carcinoma & 23 & 23.00 \\
Benign follicular nodule & 22 & 22.00 \\
Hashimoto's thyroiditis & 7 & 7.00 \\
Lymphocytic thyroiditis & 5 & 5.00 \\
Hyperplastic nodule & 3 & 3.00 \\
Adenomatous nodule & 3 & 3.00 \\
Follicular nodule & 2 & 2.00 \\
Hurthle cell neoplasm & 1 & 1.00 \\
Colloid nodule & 1 & 1.00 \\
Benign thyroid nodule & 1 & 1.00 \\
Total & 100 & 100.00 \\
Lesions & & \\
Benign & 77 & 77.00 \\
Malignant & 23 & 23.00 \\
\hline
\end{tabular}

benign lesions in $61 \%$ of the patient's malignant lesions in $29 \%$ of the patients and intermediate lesions in $10 \%$ of the patients.
Colloid goitre was the common diagnosis on FNAC noted in $32 \%$ of the patients. Based on Bethesda system for reporting 


\begin{tabular}{|c|c|c|c|c|c|c|}
\hline \multirow[t]{3}{*}{ RAGOS Criteria } & \multicolumn{4}{|c|}{ FNAC Diagnosis } & \multicolumn{2}{|c|}{ Total $(n=100)$} \\
\hline & \multicolumn{2}{|c|}{ Benign $(n=77)$} & \multicolumn{2}{|c|}{ Malignant $(n=23)$} & & \\
\hline & No. & $\%$ & No. & $\%$ & No. & $\%$ \\
\hline Benign (1) & 25 & 100.00 & 0 & 0.00 & 25 & 25.00 \\
\hline Benign (2) & 30 & 88.24 & 4 & 11.76 & 34 & 34.00 \\
\hline Intermediate (3) & 6 & 60.00 & 4 & 40.00 & 10 & 10.00 \\
\hline Malignant (4) & 15 & 65.22 & 8 & 34.78 & 23 & 23.00 \\
\hline Malignant (5) & 1 & 12.50 & 7 & 87.50 & 8 & 8.00 \\
\hline Total & 77 & 77.00 & 23 & 23.00 & 100 & 100.00 \\
\hline
\end{tabular}

\begin{tabular}{|c|c|c|c|c|c|c|}
\hline \multicolumn{7}{|c|}{ Table 6: Correlation between TI RADS score and FNAC diagnosis } \\
\hline \multirow[t]{3}{*}{ TI RADS score } & \multicolumn{4}{|c|}{ FNAC Diagnosis } & \multicolumn{2}{|c|}{ Total $(n=100)$} \\
\hline & \multicolumn{2}{|c|}{ Benign $(n=77)$} & \multicolumn{4}{|c|}{ Malignant $(\mathrm{n}=23)$} \\
\hline & No. & $\%$ & No. & $\%$ & No. & $\%$ \\
\hline Benign & 50 & 100.00 & 0 & 0.00 & 50 & 50.00 \\
\hline Not suspicious & 19 & 100.00 & 0 & 0.00 & 19 & 19.00 \\
\hline Mildly suspicious & 2 & 100.00 & 0 & 0.00 & 2 & 2.00 \\
\hline Moderately suspicious & 3 & 37.50 & 5 & 62.50 & 8 & 8.00 \\
\hline Highly suspicious & 3 & 14.29 & 18 & 85.71 & 21 & 21.00 \\
\hline Total & 77 & 77.00 & 23 & 23.00 & 100 & 100.00 \\
\hline
\end{tabular}

Table 7: Accuracy of ECI alone in the diagnosis of malignant lesion considering FNAC as standard of reference

\begin{tabular}{lllllll}
\hline ECI findings & FNAC Diagnosis & & \multicolumn{3}{c}{ Total $(\mathrm{n}=100)$} \\
& Malignant & \multicolumn{3}{c}{ Benign } & & \\
& No & $\%$ & No & $\%$ & No & $\%$ \\
$>3.1$ & 18 & 78.26 & 21 & 27.27 & 39 & 43.33 \\
$\leq 3.1$ & 5 & 21.74 & 56 & 72.73 & 61 & 67.78 \\
Total & 23 & 23.00 & 77 & 77.00 & 100 & 100.00 \\
\hline
\end{tabular}

Table 8: Accuracy of combined USE with ECI in the diagnosis of malignant lesion considering FNAC as standard of reference

\begin{tabular}{lllllll|}
\hline Radiological & FNAC Diagnosis & \multicolumn{3}{c}{ Total $(\mathrm{n}=100)$} \\
& Malignant & \multicolumn{3}{c}{ Benign } \\
& No. & $\%$ & No. & $\%$ & No. & $\%$ \\
\hline Malignant & 16 & 84.21 & 13 & 18.31 & 29 & 32.22 \\
Benign & 3 & 15.79 & 58 & 81.69 & 61 & 67.78 \\
Total & 19 & 21.11 & 71 & 78.89 & 90 & 100.00 \\
\hline
\end{tabular}

thyroid cytopathology, $77 \%$ of the patients had benign lesions and $23 \%$ of the patients had malignant lesions. Out of 23 patients with malignant lesions, papillary carcinoma was the common malignant lesion noted in 14 patients $(60.87 \%)$ followed by anaplastic carcinoma in five patients (21.74\%) and follicular carcinoma in four patients (17.39\%). Out of 77 patients with benign lesions, colloid goitre was the common benign lesion noted in 32 patients $(41.56 \%)$ followed by benign follicular nodule in 22 patients $(28.57 \%)$.

Score of four and five suggestive of malignancy was noted in 23 and eight patients respectively. Of them, $34.78 \%$ and $87.5 \%$ had malignant lesions and $65.22 \%$ and $12.5 \%$ of the patients had benign lesions on FNAC. This difference was statistically 


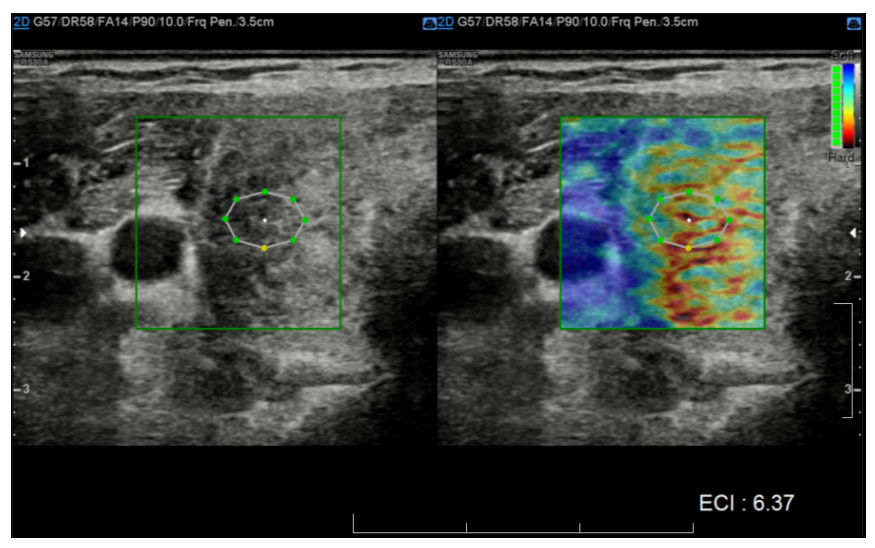

Figure 1: A 52 year old male patient whose ultrasound had hypoechic nodule, ill defined margins, TI-RADS 4, Ragos criteria 4, ECI 6.3, on FNAC, it is a papillary carcinoma and bethesda category VI on FNAC

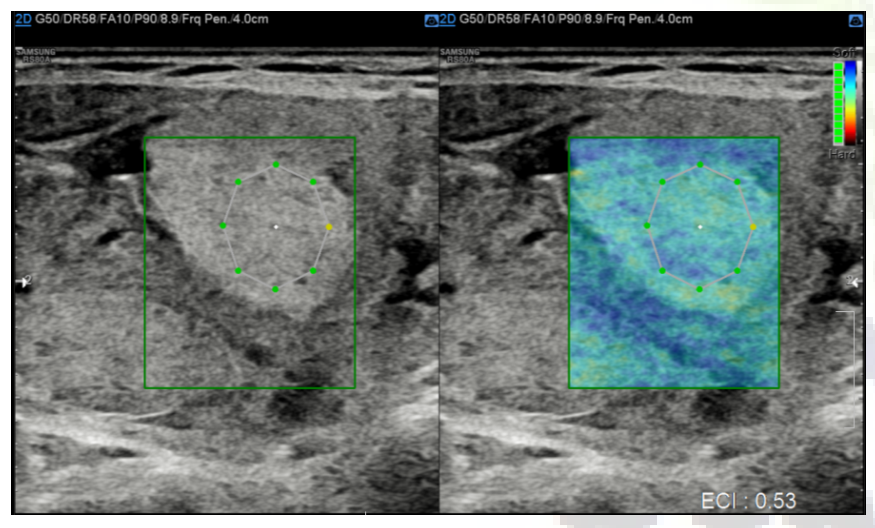

Figure 2: A 45 year old female patient whose ultrasound had spongiform hyperechoic nodule with regular margins, Ragos criteria 2, ECI 0.5, on FNAC, it is Bethesda category 2 and FNAC, it is a colloid goitre

significant $(\mathrm{p}<0.001)$.

TI RADS score suggestive of highly suspicious lesions was noted in 21 patients of them, $78.26 \%$ of the patients had malignant lesions and $3.06 \%$ of the patients had benign lesion on FNAC. This difference was statistically significant $(\mathrm{p}<0.001)$. in the diagnosis of malignant lesions was $27.27 \%$ with Specificity of $21.74 \%$, PPV $58.85 \%$ and NPV $8.20 \%$.

Malignant lesions were noted in 19 patients on FNAC. Among them, $16(84.21 \%)$ patients had malignant lesions while 3 (15.79\%) patients had benign lesions based on combined USE and ECI criteria. This difference was statistically significant $(p<0.001)$. The sensitivity of combined USE and ECI criteria in the diagnosis of malignant lesions was $84.21 \%$ with

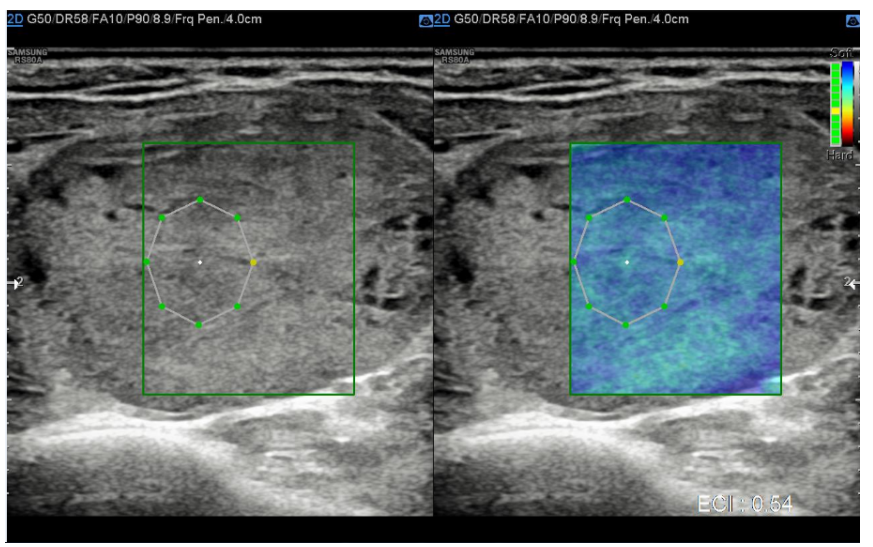

Figure 3: A 32 year old female patient, whose ultrasound had spongiform isoechoic nodule, well defined margins, ragos criteria 2, ECI 0.5, on FNAC, it is BETHESDA category II and diagnosis is benign follicular nodule

Specificity of $81.69 \%$, PPV $55.17 \%$ and NPV $95.08 \%$. ${ }^{[18]}$

Malignant lesions were noted in 23 patients on FNAC. Among them, $5(21.74 \%)$ patients had ECI $\leq 3.1$ and $18(78.26 \%)$ patients had ECI $>3.1$. This difference was statistically significant $(\mathrm{p}<0.001)$. The sensitivity of ECI.

$\mathrm{PPV}$, positive predictive value; NPV, negative predictive value; USE, combination of conventional ultrasonography and elastography; SE, strain elastography; SWE ,shear wave elastography; ND, not determined.

From the above table it is evident that the diagnostic accuracy of USE and ECI is high and in agreement with the studies by Ragazzoni et al. and Unluturk et al. but low compared to Sweel et al. However it was high compared to Kim et al. Russ et al. Moon et al. Cappeli et al. and Trimboli et al. ${ }^{[18-26]}$

Overall, USE as determined by the Ragos criteria and TI RADS score are highly associated with malignant thyroid lesions and useful in differentiating the malignant thyroid lesions from benign ones. Furthermore, radiological diagnosis by combining USE (Ragos criteria with score of four or five) along with ECI (cut of value of $\geq 3.1$ ) is highly sensitive and accurate in differentiating malignant thyroid lesions patients with completely soft benign nodules.

\section{Conclusion}

Based on the findings of this study it may be concluded that, USE as determined by the Ragos criteria, TI RADS score are highly associated with malignant thyroid lesions and useful in differentiating the malignant thyroid lesions from benign ones. Furthermore, radiological diagnosis by combining USE (Ragos criteria with score of four or five) 
Table 9: PPV, positive predictive value; NPV, negative predictive value; USE, combination of conventional ultrasonography and elastography; $\mathrm{SE}$, strain elastography; SWE ,shear wave elastography; ND, not determined.

\begin{tabular}{|c|c|c|c|c|c|c|c|c|}
\hline Study & Year & $\begin{array}{l}\text { No. of } \\
\text { cases }\end{array}$ & Type & $\begin{array}{l}\text { Sensitivity } \\
\text { (\%) }\end{array}$ & $\begin{array}{l}\text { Specificity } \\
(\%)\end{array}$ & $\begin{array}{l}\text { Accuracy } \\
(\%)\end{array}$ & PPV (\%) & NPV (\%) \\
\hline $\begin{array}{l}\text { Trimboli } \\
\text { et al. }{ }^{[18]}\end{array}$ & 2012 & 198 & SE & 97.0 & 34.0 & 50.0 & 33.0 & 97.0 \\
\hline $\begin{array}{l}\text { Ragazzoni } \\
\text { et al. }\end{array}$ & 2012 & 132 & SE & 85.0 & 83.7 & 84.1 & 69.4 & 92.8 \\
\hline $\begin{array}{l}\text { Cappelli } \\
\text { et al. }{ }^{[20]}\end{array}$ & 2012 & 159 & SE & ND & 70.8 & 73.6 & 26.3 & 100 \\
\hline $\begin{array}{l}\text { Moon et } \\
\text { al. }{ }^{[21]}\end{array}$ & 2012 & 703 & SE & 92.2 & 65.0 & 73.4 & 54.1 & 94.9 \\
\hline $\begin{array}{l}\text { Unluturk } \\
\text { et al. }{ }^{[22]}\end{array}$ & 2012 & 237 & SE & 41.0 & 93.0 & 81.0 & 67.0 & 83.0 \\
\hline $\begin{array}{l}\text { Veyrieres } \\
\text { et al. }{ }^{[23]}\end{array}$ & 2012 & 297 & SWE & 97.1 & 55.3 & ND & 22.5 & 99.3 \\
\hline $\begin{array}{l}\text { Shweel et } \\
\text { al. }{ }^{[24]}\end{array}$ & 2013 & 66 & SE & 95.4 & 94.8 & 95.2 & 82.3 & 98.8 \\
\hline $\begin{array}{l}\text { Russ et } \\
\text { al. }^{[25]}\end{array}$ & 2013 & 4,550 & SE & 98.5 & 44.7 & 48.3 & ND & 99.8 \\
\hline $\begin{array}{l}\operatorname{Kim}_{\text {al. }}{ }^{26]} \\
\text { et }\end{array}$ & 2013 & 99 & SWE & 50.0 & 80.0 & 78.6 & ND & ND \\
\hline $\begin{array}{l}\text { Present } \\
\text { study }\end{array}$ & 2017 & 100 & SWE & 84.21 & 84.69 & 82.22 & 55.17 & 95.08 \\
\hline
\end{tabular}

along with ECI (cut of value of $\geq 3.1$ ) is highly sensitive and accurate in differentiating malignant thyroid lesions patients with completely soft benign nodules. Hence patients presenting with thyroid nodules may be investigated for Gray Scale Ultrasound imaging and Ultrasound Elastography which may be helpful in preventing invasive diagnostic procedures in a substantial proportion of patients with completely soft benign nodules.

\section{References}

1. Vander JB, Gaston EA, Dawber TR. The significance of nontoxic thyroid nodule: final report of a 15 year study of incidence of thyroid malignancy. Ann Int Med. 1968;69:537537. Available from: https://doi.org/10.7326/0003-4819-69-3537.

2. Gharib H, Goellner JR. Fine-needle aspiration biopsy of the thyroid: an appraisal. Ann Int Med. 1993;118:282282. Available from: https://doi.org/10.7326/0003-4819-1184-199302150-00007.

3. Anil G, Hegde A, Chong FHV. Thyroid nodules: risk stratification for malignancy with ultrasound and guided biopsy. Cancer Imaging. 2011;11(1):209-223. Available from: https://dx.doi.org/10.1102/1470-7330.2011.0030.

4. Refaat R, Kamel A, Elganzory M, Awad NM. Can real-time ultrasound elastography using the color score and strain ratio differentiate between benign and malignant solitary thyroid nodules? EJRNM. 2014;45(1):75-87. Available from: https: //dx.doi.org/10.1016/j.ejrnm.2013.12.005.

5. Nasuti JF, Gupta PK, Baloch ZW. Diagnostic value and costeffectiveness of on-site evaluation of fine-needle aspiration specimens: Review of 5,688 cases. Diagn Cytopathol. 2002;27(1):1-4. Available from: https://dx.doi.org/10.1002/dc. 10065.

6. Chandwale S, Singh N, Kumar H, Pradhan P, Gore C, Rajpal M. Clinicopatholological correlation of thyroid nodules. Int $\mathrm{J}$ Pharm Biomed Sci. 2012;3(3):97-102.

7. Park SH, Kim SJ, Kim EK, Kim MJ, Son EJ, Kwak JY. Interobserver agreement in assessing the sonographic and elastographic features of malignant thyroid nodules. Am J Roentgenol. 2009;193:416-439.

8. Gharib H, Papini E, Paschke R, Duick DS, Valcavi R, Hegedus L. Associazione Medici Endocrinologist, and European Thyroid Association Medical Guidelines for Clinical Practice for the Diagnosis and Management of Thyroid Nodules. Endocr Pract. 2010;16:1-43.

9. Arunkumar MM, Ahuja S, Tk C, Padhya AK, Gupta AK, Kapila K. Sonography and Radionuclide Scanning in solitary thyroid nodule. J Asso Physicians India. 1992;40:302-302.

10. Garg S, Mohan H, Nagarkar N, Handa U. Role of fine needle aspiration cytology in diagnosis and -management of thyroid lesions: A study on 434 patients. J Cytol. 2008;25(1):13-13. Available from: https://dx.doi.org/10.4103/0970-9371.40652. 
11. Ophir J, Cespedes I, Ponnekanti H, Yazdi Y, Li X. Elastography: a quantitative method for imaging the elasticity of biological tissues. Ultrason. 1991;13:111-134. Available from: https://doi.org/10.1016/0161-7346(91)90079-W.

12. Asteria C, Giovanardi A, Pizzocaro A, Cozzaglio L, Morabito A, Somalvico F, et al. US-Elastography in the Differential Diagnosis of Benign and Malignant Thyroid Nodules. Thyroid. 2008;18(5):523-531. Available from: https://dx.doi.org/10. 1089/thy.2007.0323.

13. Cosgrove D, Piscaglia F, Bamber J, Bojunga J, Correas JM, Gilja $\mathrm{O}$, et al. EFSUMB Guidelines and Recommendations on the Clinical Use of Ultrasound Elastography.Part 2: Clinical Applications. Ultraschall Med. 2013;34(03):238-253. Available from: https://dx.doi.org/10.1055/s-0033-1335375.

14. Liu BX, Xie XY, Liang JY, Zheng YL, Huang GL, Zhou LY, et al. Shear wave elastography versus real-time elastography on evaluation thyroid nodules: a preliminary study. Eur J Radiol. 2014;83(7):1135-1178. Available from: https://doi. org/10.1016/j.ejrad.2014.02.024.

15. Tian W, Hao S, Gao B, Jiang Y, Zhang X, Zhang S, et al. Comparing the Diagnostic Accuracy of RTE and SWE in Differentiating Malignant Thyroid Nodules from Benign Ones: a Meta-Analysis. Cell Physiol Biochem. 2016;39(6):2451-63. Available from: https://doi.org/10.1159/000452513.

16. Aliasgarzadeh A, Tarzemani MK, Raeisi M, Mobasseri M, Mozayyan M, Ghojazadeh M. Diagnostic value of Elastography in thyroid nodules. J Anal Res Clin Med. 2014;2(2):71-77.

17. Popoveniuc G, Jonklaas J. Thyroid Nodules. Med Clin North Am. 2012;96(2):329-349. Available from: https://dx.doi.org/ 10.1016/j.mena.2012.02.002.

18. Trimboli P, Guglielmi R, Monti S, Misischi I, Graziano F, Nasrollah N, et al. Ultrasound Sensitivity for Thyroid Malignancy Is Increased by Real-Time Elastography: A Prospective Multicenter Study. J Clin Endocr Metab. 2012;97(12):4524-4530. Available from: https://dx.doi.org/10. 1210/jc.2012-2951.

19. Ragazzoni F, Deandrea M, Mormile A, Ramunni MJ, Garino F, Magliona G, et al. High Diagnostic Accuracy and Interobserver Reliability of Real-Time Elastography in the Evaluation of Thyroid Nodules. Ultrasound Med Biol. 2012;38(7):1154-1162. Available from: https://dx.doi.org/10. 1016/j.ultrasmedbio.2012.02.025.

20. Cappelli C, Pirola I, Gandossi E, Agosti B, Cimino E, Casella C. Real-time elastography: a useful tool for predicting malignancy in thyroid nodules with nondiagnostic cytologic findings. $\mathrm{J}$ Ultrasound Med. 2012;31:1777-82. Available from: https: //doi.org/10.7863/jum.2012.31.11.1777.
21. Moon HJ, Sung JM, Kim EK, Yoon JH, Youk JH, Kwak JY. Diagnostic performance of gray-scale US and elastography in solid thyroid nodules. Radiology. 2012;262:1002-1015. Available from: https://doi.org/10.1148/radiol.11110839.

22. Unlütürk U, Erdoğan MF, Demir O, Güllü S, Başkal N. Ultrasound elastography is not superior to grayscale ultrasound in predicting malignancy in thyroid nodules. Thyroid. 2012;22:1031-1039. Available from: https://doi.org/10.1089/ thy.2011.0502.

23. Veyrieres JB, Albarel F, Lombard JV, Berbis J, Sebag F, Oliver $\mathrm{C}$, et al. A threshold value in Shear Wave elastography to rule out malignant thyroid nodules: A reality? Eur J Radiol. 2012;81(12):3965-3972. Available from: https://dx.doi.org/10. 1016/j.ejrad.2012.09.002.

24. Shweel M, Mansour E. Diagnostic performance of combined elastosonography scoring and high-resolution ultrasonography for the differentiation of benign and malignant thyroid nodules. Eur J Radiol. 2013;82(6):995-1001. Available from: https: //dx.doi.org/10.1016/j.ejrad.2013.02.002.

25. Russ G, Royer B, Bigorgne C, Rouxel A, Bienvenu-Perrard M, Leenhardt L. Prospective evaluation of thyroid imaging reporting and data system on 4550 nodules with and without elastography. Eur J Endocrinol. 2013;168(5):649-655. Available from: https://dx.doi.org/10.1530/eje-12-0936. doi:10.1530/eje12-0936.

26. Kim H, Kim JA, Son EJ, Youk JH. Quantitative assessment of shearwave ultrasound elastography in thyroid nodules: diagnostic performance for predicting malignancy. Eur Radiol. 2013;23:2532-2539. Available from: https://doi.org/10.1007/ s00330-013-2847-5.

Copyright: (C) the author(s), 2020. It is an open-access article distributed under the terms of the Creative Commons Attribution License (CC BY 4.0), which permits authors to retain ownership of the copyright for their content, and allow anyone to download, reuse, reprint, modify, distribute and/or copy the content as long as the original authors and source are cited.

How to cite this article: Ramakrishna R, Thatipamula M. Efficacy of Ultrasound Intrinsic Compression Strain Elastography in Prediction of Malignancy in Thyroid Nodules with Fine Needle Aspiration Cytology Correlation. Asian J. Med. Radiol. Res. 2020;8(2):9-17.

DOI: dx.doi.org/10.47009/ajmrr.2020.8.2.2

Source of Support: Nil, Conflict of Interest: None declared. 